Recensão:

GRONDIM, Marcelo \& VIEZZER, Moema. Abya Yala! - Genocídio, Resistência e Sobrevivência dos Povos Originários das Américas. Rio de Janeiro, Bambual Editora, 2021.

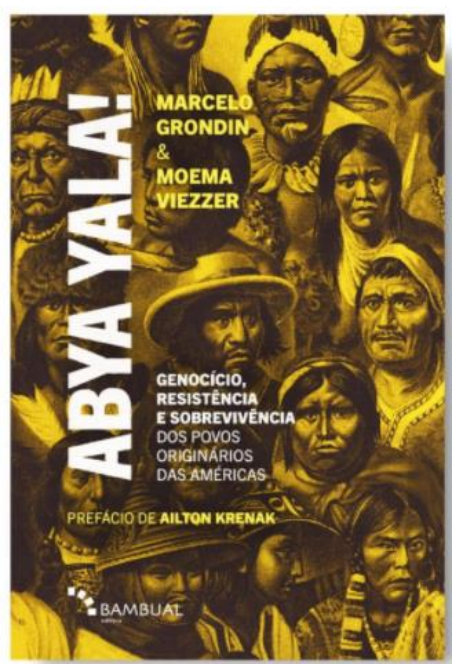

\title{
Abya Yala, a retomada do primeiro amor
}

\section{Marcelo Barros ${ }^{1}$}

Retomar o primeiro amor é a proposta feita, quando o caminho da aliança comunitária se perde em desvios que nos fazem perder o rumo. Na tradição bíblica, essa expressão era usada quando o povo esquecia o projeto de uma sociedade baseada na justiça. No último livro do Novo Testamento, retomar o primeiro amor é o apelo do Cristo à Igreja de Éfeso $(A p 2,5)$.

O livro "Abya Yala, Genocídio - Resistência - Sobrevivência dos povos originários do atual continente americano" de Marcelo Grondin e Moema Viezzer representa um forte chamado para recuperarmos neste continente o encanto do primeiro amor social. O próprio título do livro remete ao nome programático para um continente que, em nossos tempos, redescobre sua identidade original e quer refazer a energia vital de amor que a conquista e as diversas etapas de colonização violentaram.

Para os povos andinos, desde a conquista, o mundo está de cabeça para baixo e é necessário reconstituir o Pachacuti, ou seja, o equilíbrio de amor representado pela energia da Pachamama, (que os afrodescendentes chamam de Axé) o amor que fecunda o universo.

Abya Yala era o nome que no seu idioma original, o povo Kuna, natural da Serra Nevada, no norte da Colômbia e, atualmente, residente na costa leste do Panamá, dá ao conjunto de todas as regiões da atual América. Abya Yala significa "Terra Viva", ou ainda "Terra que floresce".

\footnotetext{
${ }^{1}$ Marcelo Barros é teólogo e assessor de movimentos sociais e das comunidades eclesiais de base. Tem 58 livros publicados no Brasil, dos quais o mais recente foi escrito em coautoria com Henrique Vieira: O Monge e o Pastor, Ed. Objetiva, 2020.
} 
No Brasil, os Tupis chamavam esta terra de Pindorama. Nos Andes, até hoje se fala em Tawantinsuyu. No entanto, atualmente, a expressão Abya Yala tem voltado a significar o conjunto deste imenso território que cobre o que os europeus decidiram denominar América.

Em nossos dias, a civilização ocidental afunda em uma crise multifacetada e com consequências trágicas. Para a sustentabilidade do planeta e a justiça eco-social entre os povos, precisamos de uma nova aliança da humanidade. A redescoberta e o diálogo com as culturas dos povos originários e suas tradições podem ser fonte de sabedoria e bem-viver para todos os seres humanos. No entanto, para que este diálogo possa ser justo e fecundo, é fundamental assumirmos a história e realizarmos uma purificação da memória. Para isso, temos de assumir o relato trágico, e ainda pouco contado, do maior genocídio da história da humanidade, praticado desde cinco séculos contra os povos originários das Américas.

Conforme Ailton Krenak, irmão e companheiro que escreve o prefácio deste livro, esta guerra de massacre e genocídios contra as comunidades indígenas ainda não terminou. E parece cada dia mais violenta. Em termos de violência e de crueldade, a realidade narrada de forma fiel por Marcelo Grondin e Moema Viezzer deixa qualquer filme de faroeste ou de terror que o Cinema possa ter produzido, longe da atrocidade real.

Os autores resumem esta hecatombe em cinco partes:

Depois de uma introdução sobre as conquistas europeias, a primeira parte do livro relata o genocídio dos povos que viviam no atual Caribe. A segunda parte conta o extermínio dos povos originários do México, sua resistência e atual organização. A terceira parte nos leva para os Andes centrais: "do Império do Sol a "um novo lugar ao sol", e se encerra com a descrição esperançosa como experiência ímpar: o estado plurinacional da Bolívia. A quarta parte tem um título significativo e que, a cada dia, se comprova atual: "Brasil: o genocídio que ainda não acabou". A quinta parte é dedicada aos Estados Unidos da América do Norte: "Limpeza étnica como política de Estado" e a sexta e última parte se intitula "Um novo começo".

Ao ler esta longa história, resumida em pouco mais de 200 páginas, nós nos defrontamos com a história trágica do maior genocídio da história da humanidade: 70 milhões de vítimas entre os povos originários das Américas. Apesar disso, em cada página, por trás de cada palavra, quem ler se sentirá chamado à solidariedade e a entrar em uma nova aliança da humanidade pelo bem-viver. E esta aliança só será possível se for construída a partir dos mais excluídos entre os excluídos da história: os povos indígenas.

Juntos com eles, estamos todos e todas, em busca de um céu no qual caiba a vastidão de nossos sonhos e de uma noite de estrelas que acolha a esperança que temos no projeto de mundo no qual acreditamos. Este livro é fundamental para construirmos este outro mundo, necessário e possível. 
Marcelo Grondim é doutor em Ciências Sociais e latino-americanista que viveu em vários países do continente. Moema Viezzer, sua esposa, é uma grande educadora e escritora, com mestrado em Ciências Sociais e grande experiência de militância eco-social. O testemunho da vida deles transparece para nós em vários momentos de sua narrativa. Eles mostram que, atualmente, em todas as partes da nossa Abya Yala, movimentos sociais, comunidades indígenas e grupos afrodescendentes se organizam e tomam um protagonismo novo. Apesar de que os impérios sempre tentam destruir a resistência indígena e negra, nunca conseguirão. Como cantava Maria Helena Walsh na voz índia de Mercedes Sosa:

\section{"Tantas veces me mataron, Tantas veces me morí Sin embargo estoy aqui, Resucitando Gracias doy a la desgracia y a la mano con puñal Porque me mató tan mal $Y$ seguí cantando}

O sangue deste martírio coletivo e os espíritos destes milhões de Encantados fecundam a atual caminhada. O segredo dela é a sua mística. Por isso, podemos, com o Popol Vuh, livro sagrado dos povos Maia, gritar: "Que todos se levantem, que todos sejam convidados, que ninguém permaneça atrás. Que desponte já a alvorada". 